Forthcoming in New Blackfriars vol. 100, 2019 DOI:10.1111/nbfr.12423

\title{
It's Déjà vu all over again ${ }^{1}$
}

\author{
John Haldane
}

\begin{abstract}
The latest sex abuse scandal in the American Catholic Church involving Cardinal McCarrick is compared with that of 2002 in the archdiocese of Boston, and that of 2012 involving Cardinal O'Brien of St Andrews and Edinburgh. Attention is given to aspects of the latter in part because of the privileged perspective of the author. Thereafter, sociological and other reasons are proposed as to why the Catholic priesthood has been afflicted with cases of sexual abuse and sexual impropriety. The issue is considered of the genesis of homosexuality, and apriori assumptions are rejected taking it instead to be an empirical question. There is analysis of the common distinction between (homosexual) orientation and activity, and of its relevance to the issue of admission to seminary formation. Noting that Vatican documents and statements do not refer to 'orientation' but to 'deep-seated homosexual tendencies' (tendenze omosessuali profondamente) these notions are related to those of disposition and activity, and it is argued that the important distinction is between orientation and the rest. Finally, it is noted that both traditional and progressive Catholics are often given to idolatry about the Church and Pelagianism about their faith and practice.
\end{abstract}

\section{Keywords}

McCarrick, O’Brien, abuse scandal, homosexuality, idolatry, Pelagianism.

Here we go again

My title is a phrase attributed to the famous Italian-American baseball player, manager and coach Yogi Berra. Among other 'yogi-isms' relevant to the present situation are the sayings that 'you can observe a lot by watching', that 'when you come to a fork in the road, take it' and that 'it ain't over till it's over'. The following reflections are in response to the latest sex abuse scandal in the American Church involving the behaviour of Cardinal McCarrick and other reports of sexual wrongdoing and episcopal cover-ups, but I will also discuss a prominent non-US case, in part to broaden the scope but also because while there are

${ }^{1}$ Based on the text of the opening lecture of a conference on the theme 'The Future of the Catholic Church After the Scandals of 2018' organized by the Thomistic Institute and First Things and held at the Dominican House of Studies in Washington DC on September 8, 2018. I am grateful to the organisers for the invitation to speak and to President John Garvey of Catholic University of America for his response. 
similarities there are also differences between the two circumstances and there may be things to be learned from the UK case and from the responses to it, as much as from the former. In part, I write from the perspective of a witness and ongoing commentator in evidence of how little has changed.

I began observing the abuse scandal first in the US Church early in 2002 when I followed the Boston Globe's exposure of sexual abuse by Catholic clergy in that city and the response to it of Cardinal Law and other bishops. At the time I was serving as a visiting Professor of Humanities at Georgetown in Washington D.C. where in the previous year McCarick had been installed as Archbishop and made a Cardinal. In May and June, between attending the Vatican meeting of all American Cardinals called by John Paul II to discuss the 'American Problem' of sexual abuse and cover-up, and the forthcoming meeting of three hundred American bishops in Dallas, McCarrick gave a number of press interviews from which I extract two passages:

You want someone who can live a chaste life; that is key for me. If somebody who would like to go into the seminary says, "All my life, I've tried to be chaste, I'm a heterosexual, and I have tried to be celibate, and I have proven that I can be," I think you say "Fine." If someone says to you, "All my life I've tried to be chaste, I have a homosexual orientation, but I've always tried to be chaste," I think you do that one case by case. ... It might be that the overwhelming weight of opinion will say that homosexuals should not be ever admitted to seminary. I'm not there yet. But if that's what they tell me to do, then that's what we'll do. Certainly, I'm there if we say anyone who has been active in a gay life should not be admitted. ${ }^{2}$

This crisis is more important than any crisis we've had in my time. Our people are waiting for the bishops to say, O.K., we've got it under control, we're on the same page, we hear you and we've listened to you and now you can be sure that this will never happen again. ${ }^{3}$

In light of subsequent exposures two points may be worth noting: first, the phrase "and I have proven that I can be" appended to "I'm a hetrosexual, and I have tried to be celibate" is not repeated following "I have a homosexual orientation, but I've always tried to be chaste"; second, the aspiration to get the crisis under control clearly was unfulfilled, in no small part because the US Conference of Catholic Bishops' Dallas 'Charter for the Protection of Children and Young People' only refers to priest and deacon abusers, exempting bishops from its scope. This was not an oversight but a decision of the drafting committee.

In the same month as Cardinal's McCarick's New York Times interview I gave a public lecture at Georgetown in which I said of the then prevailing situation:

2 'Interview with Cardinal McCarrick', USA Today 20 May 2002, https://usatoday30.usatoday.com/news/nation/2002/05/20/transcript.htm

${ }^{3}$ L. Goldstein, 'Bishop Quits as Others Prepare to Meet on Abuse Scandal', New York Times 12 June 2002, https://www.nytimes.com/2002/06/12/us/bishop-quits-as-others-prepare-tomeet-on-abuse-scandal.html 
The Catholic Church in America is in serious trouble and no proper interest is served by pretending otherwise, or by suggesting that this is a storm that will pass in a few months. The causes of the difficulties remain and the effects will extend for years to come and are already being felt beyond America itself. The immediate issue, of course, is that of sexual vice among clergy and religious, and the failure of bishops and superiors to take adequate measures against wrongdoers, and to protect the innocent from being preyed upon by them. So we have the sorry state of multiple offenders being exposed and in some cases imprisoned, and of Bishops, Archbishops and Cardinals being roundly condemned from within as well as outwith the Church. The image of a hierarchy concerned to protect itself and the Church even at great cost to innocents has created a general impression of a failed organisation letting down both its own members as well as the wider world to which it had promised much: in effect, an ecclesiastical Enron. ${ }^{4}$

\section{Trouble back home}

A decade after the Boston revelations I found myself much closer to another exposure of scandalous conduct within the Catholic Church, this time in my native country, Scotland, and in my own archdiocese. It involved the behavior of the late Keith Patrick Cardinal O'Brien, Archbishop of St Andrews and Edinburgh. The exposure was of sexual relations with fellow priests and seminarians allegedly ranging over a thirty-year period dating from a time when he was on the staff of two seminaries, through his nomination as Archbishop in 1985 beyond the point in 2003 when he was appointed Cardinal. There are resemblances between the careers of the two men: they are of the same generation, McCarrick was born in 1930, O'Brien in 1938; both were nominated archbishops (in 1988 and 1985) and elevated to the Cardinalate (in 2001 and 2003) by Pope John Paul II; both were also appointed to the Vatican's Pontifical Council for the Pastoral Care of Migrants and Itinerant People and overlapped in the period of their membership, and like O'Brien, McCarrick is also accused of sexual advances towards and sexual activity with seminarians and priests. ${ }^{5}$

I commented on the 2002 US revelations in both secular and religious British publications, and on the 2013 O'Brien scandal for UK and international media, and today

${ }^{4}$ Following a scandal in which it was revealed that Enron was 'sustained by institutionalized, systematic, and creatively planned fraud' the corporation's stock value collapsed and it filed for bankruptcy on December 2, 2001. Since then, fifteen US Catholic dioceses and three religious orders have petitioned for bankruptcy due to the clergy sexual abuse crisis, for details http://www.bishop-accountability.org/bankruptcy.htm.

${ }^{5}$ The issue of seminarians is usually cited but in his letter addressed to Bishop McElroy and dated 28 July 2016 Richard Sipe writes "has been reported by numerous seminarians and priests of sexual advances and activity. A settlement with one priest was effected by Stephen Rubino, Esq. In that record the operation of McCarrick in sexual activity with three priests is described." http://www.awrsipe.com/Correspondence/McElroy-2016-07-28-rev.pdf 
find myself thinking that what I wrote and said in the past could equally well be said again now. Indeed, I am repeating part of it here because the main points are still relevant, and because the fact that they are so indicates that these years later the principle issues remain largely unaddressed. One lesson from the repeat of past failures is that, if left to their own devices, it is likely that bishops, bishops conferences, presidents of bishops conferences, Roman dicasteries, and the Council of Cardinal Advisers, will find ways of not confronting the problems. Time may be short when there could still be an effective non-ideological layled enquiry; if that does not occur, and even if it does, matters may lie with civil authorities for whom this will be an opportunity to condemn the Catholic Church more broadly.

\section{O'Brien: A more complex case and response}

When credible and substantiated allegations are made against senior Church figures it is common enough that colleagues and acquaintainces will say 'I had no idea of this' and, as in the recent case of Cardinal McCarrick, that is increasingly met with scepticism; but I think it is often in the nature of these matters that perpetrators effectively partition and mask their darker selves. Archbishop O'Brien was a well-known and well-liked figure within the Catholic Church in Scotland, in Britain and more widely, and prior to the publication in early 2013 of allegations against him I do not recall any talk about his sexual misconduct. I knew O'Brien personally, met him in different contexts and found him friendly, compassionate, responsive and generous of his time; but I am also aware that some of his clergy had a different view finding him cliquish, partisan and given to favouritism. I had also heard it said by someone who had more extensive dealings with him that he was narcissistic.Certainly at any public or semi-public event he would be accompanied by a photographer and pictures would appear in the national Catholic newspaper the Scottish Catholic Observer; but this practice could also be attributed to a reasonable wish to have events reported for the sake of the organizing group, to give signs of his own involvement in activites, again an encouragement to the faithful, and more generally to promote the sense of a buoyant Church. He was also politically alert using his position to give public voice to Catholic concerns about issues such as nuclear deterrence policy (which he opposed), the treatment of asylum seekers (which he felt was draconian), poverty, the protection of Catholic education, and the relation between sexual ethics and public policy, particularly with respect to homosexuality.

In 2004 I gave the laureation address when he received an Honorary Doctorate from the University of St Andrews; ${ }^{6}$ of which the following is an extract:

\footnotetext{
${ }^{6}$ Subsequent to the revelations of his sexual improprieties a member of the University led a campaign to have the honorary degree revoked. The Senate Business Committee considered the issue and chose not to revoke it stating that "After discussion, Committee members agreed there was no case to recommend to Senate that the degree be revoked, and that it considered the matter closed. SBC recognises that universities award honorary degrees in good faith on the basis of evidence available to them at a point in time, that revocation cannot change or ameliorate the wrongs of the past and that, notwithstanding the very real hurt and loss caused by the actions of the honorand, it would be no more than an empty gesture." To date, of the
} 
In a country such as Scotland in which the history of Catholicism is ancient but disturbed, a Cardinal brings standing to his Church but also has to make little of the idea that he is an ecclesiastical aristocrat. Archbishop O'Brien has shown himself to be sensitive to this need and has won the admiration of those in other Churches and faiths. ... elevated as [his various offices and titles] are, their only real value is as marks of Christian charity and commitment, and those virtues are made neither greater nor less by being honoured.

Every Bishop is strictly speaking a people's Bishop, but not every holder of high ecclesiastical office lives as if that were so. Keith Patrick O'Brien is an example of priestly service: with his people in times of celebration and in times of trouble; encouraging children towards the future and comforting the aged as their lives pass away. In that last connection I may give personal testimony as I recall Archbishop O'Brien visiting my mother here in St Andrews towards the end of her life bringing the spiritual grace of the blessed sacrament and the human comfort of his own kindly manner.

Two years later in 2006 I did a newspaper interview with him in the Catholic Herald that was widely reported owing to the support he voiced for the cause of Scottish Independence. This provoked the Prime Minister Tony Blair into a sharp dismissal parodied at the time as akin to Henry II's 'turbulent priest' compliant against Archbishop Becket. O'Brien's was a two-pronged political move: intended on the one hand to rattle the Labour Party in Scotland which had long been the principal recipient of Catholic votes but which had become more secular and challenging of Catholic schools and Catholic moral teaching; and on the other to win concessions for Catholic interests from the Scottish National Party (which in the following year displaced Labour as the governing Party in the Scottish Parliament). Around the same time O'Brien began a series of public criticisms of same-sex civil partnerships, adoption, and later what advocates had by then termed 'equal marriage'. In December 2011 during a Scottish government consultation on that issue he stated:

The empirical evidence is clear, same-sex relationships are demonstrably harmful to the medical, emotional and spiritual well-being of those involved. No compassionate society should ever enact legislation to facilitate or promote such relationships, we have failed those who struggle with same-sex attraction and wider society by our actions. ${ }^{7}$

This brought severe criticism from gay-rights and marriage equality activists and from the media generally. Yet three months later he published an article in a Sunday paper in which

nine US colleges and universities that awarded Archbishop McCarrick honorary degrees three have revoked them: Portland, Fordham and CUA, the last of which was his alma mater where he earned MA and $\mathrm{PhD}$ and served as chaplain, dean of students, director of development, chancellor and trustee.

7 'Scotland fails homosexual people', Scottish Catholic Observer 16 December 2011, http://www.sconews.co.uk/latest-edition/14858/scotland-fails-homosexual-people/ 
he returned to the subject in relation to a similar consultation in England and Wales. $\mathrm{He}$ wrote:

Since all the legal rights of marriage are already available to homosexual couples, it is clear that this proposal is not about rights, but rather is an attempt to redefine marriage for the whole of society at the behest of a small minority of activists. Redefining marriage will have huge implications for what is taught in our schools, and for wider society. It will redefine society since the institution of marriage is one of the fundamental building blocks of society. The repercussions of enacting same-sex marriage into law will be immense. ... But can we simply redefine terms at a whim? Can a word whose meaning has been clearly understood in every society throughout history suddenly be changed to mean something else?

... In Article 16 of the Universal Declaration on Human Rights, marriage is defined as a relationship between men and women. But when our politicians suggest jettisoning the established understanding of marriage and subverting its meaning they aren't derided. Instead, their attempt to redefine reality is given a polite hearing, their madness is indulged. Their proposal represents a grotesque subversion of a universally accepted human right. ${ }^{8}$

Once again he was denounced in the media, and later in November 2012 was named 'Bigot of the Year' by Stonewall UK; but his intervention was especially welcomed by defenders of traditional marriage on its own account and as contrasting with the more muted response of English bishops. The Scottish and English Churches are separate but at the time Cardinal O'Brien was often described as 'Britain's most senior Catholic' because the Archbishop of Westminster (Vincent Nichols) who is the primate in England and Wales had not then been elevated to the cardinalate. Archbishop O'Brien's protestations secured him strong support among moral and social conservatives and increased calls for corresponding leadership from Westminster Cathedral. In the week following O'Brien's article, Archbishop Nichols was interviewed by BBC television and asked what he would say to a gay couple seeking to be married. He replied:

I would want to say to them that I understand their desires, that I understand their experience of love is vitally important in their lives, but I would want to say to them that they are called in my view, in the Church's view, to a very profound friendship in life. I would want them to be respected, but I would want them to have a vision in themselves that what they are called to is not marriage but a very profound and lifelong friendship. ${ }^{9}$

\footnotetext{
${ }^{8}$ Keith O'Brien, 'We cannot afford to indulge this madness', Sunday Telegraph 4 March 2012 https://www.telegraph.co.uk/comment/9121424/We-cannot-afford-to-indulge-thismadness.html

${ }^{9}$ M. Holehouse, 'Gay couples are just lifelong friends, says Catholic leader', Daily Telegraph, https://www.telegraph.co.uk/news/religion/9147559/Gay-couples-are-just-lifelong-friendssays-Catholic-leader.html
} 
Nine months later, in his Christmas Midnight Mass sermon at Westminster Cathedral he directed a criticism, as O'Brien had done, if less pointedly, to 'governments':

Sometimes sexual expression can be without the public bond of the faithfulness of marriage and its ordering to new life. Even governments mistakenly promote such patterns of sexual intimacy as objectively to be approved and even encouraged among the young. ... ${ }^{10}$

\section{The aftermath}

The general impression in the UK was that the Archbishop of Westminster had been pressured into public statements by the voluble and forthright interventions of the Cardinal across the border. As this brief account suggests, prior to the revelations of his own conduct Archbishop O'Brien was generally seen in a favourable light by Catholic and other social conservatives, while positively regarded by liberals at least in relation to his advocacy of peace and social justice causes. This may explain why the reaction to the later allegations against him, which he initially sought to deny were more muted than have been those to the McCarrick revelations; though responses from LGBT groups and their supporters ranged from accusations of gross hypocrisy to suggestions that like other gay priests he was himself a victim of the Church's homophobia.

In Spring 2013 following O'Brien's exposure I was frequently in the UK press, and on TV and radio commenting on the then crisis and defending the Church more broadly against varities of critics for whom the Cardinal's exposure was an expected and fruitful gift. This was the period of Pope Benedict's 'resignation and the pre-election interlude', or of his 'abdication and of the interregnum': the fact that there was some disagreement among Catholics over the use of these phrases is itself evidence of a politico-cultural divide to which I will return. At that point, however, I thought it possible that one effect of the O'Brien revelations, and of the previous decades of public exposure of priestly abuse and episcopal mismanagement and cover-up, might be that the Conclave would take the opportunity to elect someone who would make a pontifical priority of addressing clergy sexual abuse and impropriety, and episcopal malfeasance. In an article in of 25 February I wrote:

... given the suspicion of US political power, and widespread opposition to its foreign policies it is hard for the case for an Anglosphere candidate to be pressed by an American. Yet it might well be that what the Church now needs is the robust, clear-out, can-do style that would come with say Cardinal Dolan, Archbishop of New York or perhaps with Cardinal Pell, Archbishop of Sydney. Such choices were already unlikely as the Italians aspire to recover the Papacy, and the developing nations of the southern hemisphere, where

10 J. Fahey, 'Archbishop of Westminster attacks gay marriage plan' https://www.independent.co.uk/news/uk/home-news/archbishop-of-westminster-attacks-gaymarriage-plan-8430997.html 
most of the world's one billion plus Catholic live, hope to see one of their own elected. Given the tragedy of Cardinal O'Brien's situation the cause of an Anglo-Pope may be further weakened. ... [with his exposure] another blow has fallen upon the faithful but maybe it will be the one to awaken them to the need to serve the Church rather than to assume they will be served by it. Cardinal O'Brien's resignation will further sap the morale of clergy and laity alike but it could also be a turning point, a time of new beginnings. ${ }^{11}$

The latter comment was more an expression of pious hope and an effort at encouragement than an expectation, and to date there is no evidence of what I hoped for. Two weeks later the Conclave reached what may be regarded as a compromise between the two constituencies I had mentioned: an Argentinian of Italian heritage, and Pope Francis's pastoral manner brought some relief from the secular attacks but not, at least to date, a robust, clear-out, can-do style. Indeed, he soon became another object of the Catholic culture wars: lauded by liberals and critcised by conservatives.

\section{A troubled priesthood}

In the week prior to the papal election I wrote a second Tablet piece on the O'Brien expose, in which I noted that there is another difficult fact to be faced which many would prefer were not mentioned, but that there could be no progress until it is managed, however that should be done. In the $19^{\text {th }}$ and first half of the 20th centuries the domestic junior and senior seminaries offered the sons of working class families a high-quality education; but with the socio-economic rise of Catholics came access to other forms of education and the intellectual standards in the seminaries declined. Further to that, the seminaries provided escape for those who were uncertain about their heterosexuality and who would otherwise face questions about girlfriends and married life. The result of these two factors is many clergy who have relatively little in the way of rigorous intellectual formation and are struggling with or indulging their sexuality. The evidence of this has been known for a long time and been a common theme of conversation among the laity and other clergy.

Some current American estimates suggest that perhaps more than half of those in or training for the priesthood and religious life are homosexual, and similar figures have been speculated about for elsewhere in the developed world. This is massively disproportionate to the percentage of homosexuals in the population at large. Why should this be so? Two answers suggest themselves. First that religious life has become one of the gay occupations, a place where people of like sexuality can keep company with a degree of ease due to mutual recognition, acceptance and companionship. To some degree this has been so for centuries. Second, that apart from its positive attraction for homosexuals it is losing its appeal for heterosexual men. The latter fact as well as being linked with the former, is also connected with celibacy which is increasingly at odds with highly sexualised secular lifestyles. But it is also likely to be related to the earlier point that the priesthood

11 'Still Waiting' The Tablet, 19 October 2012. 
once offered rare opportunities that are more generally available to now affluent members of those historically underprivileged communities from which vocations were drawn.

There will continue to be scandals until the issue of homosexuality in the priesthood and religious life is adequately addressed - and it is genuinely hard to do so in a situation of rapidly declining numbers of clergy and in which any suggestion of a problem is met with accusations of 'homophobia'. Unlike some, I do not believe that homosexuality per se is the problem, rather it is the existence of large numbers of homosexuals in a morally, spiritually and intellectually weakened institution that regards this 'tendency' as intrinsically disordered and is reluctant to admit that its priesthood is subject to that very condition, while in the wider world and among the laity there is increasing acceptance and even celebration of active homosexual life.

Getting some things clearer.

In a sincere effort to exercise pastoral sensitivity and in response to charges of homophobia, senior Church figures, Cardinal McCarrick included, have often emphasised that the Church does not condemn homosexual orientation only homosexual acts. Though theologically well-intentioned this language contributes to a confused message and encourages the reaction that if the first is acceptable how can acting on that orientation be wrong. Herein there is equivocation, or at least insufficient distinction between orientation and disposition. Interestingly, the expression used in official Roman documents and in Papal addresses on the issue, such as the 1992 Catechism of the Catholic Church, the 2005 Instruction Concerning the Criteria for the Discernment of Vocations with regard to Persons with Homosexual Tendencies in view of their Admission to the Seminary and to Holy Orders, the 2016 Congregation for Clergy 'Gift of Priestly Vocation', and most recently in May 2018, Pope Francis's address to the General Assembly of the Italian Bishops Conference is not 'orientation' but 'deep seated tendencies' in Italian tendenze omosessuali profondamente. ${ }^{12}$ The significance of this difference will become clear.

First, however, it is important to accept that the determining forces of sexual nature are still not well understood. Some Catholic writers and commentators insist that 'no-one is born gay' and that same sex attraction is the result of relationship failures in early childhood, but while scientific studies are often referred to, this claim has about it the character of an a priori thesis immune to empirical refutation. There are probably two reasons for this attitude a psychological and a theological one. The first is the desire that someone who is subject to same-sex attraction may overcome or be freed of this. If you believe it to be a malady then it is natural that you should want it remedied and that is likely to seem more achievable if it is an acquired rather than an inborn condition, such is the reationale of the reparative therapy movement. The second is the belief that if it were inborn then one or other of two consequences follow: either a) God intended that someone should

${ }^{12}$ On the last see Salvatore Cernuzio, "If there is any doubt about homosexuality, better not let them enter the seminary', La Stampa, 24 May 2018

http://www.lastampa.it/2018/05/24/vaticaninsider/if-there-is-any-doubt-about-homosexualityit-is-better-not-to-let-them-enter-the-seminary-R11b1wdJOWXcOD9Nn2tZmO/pagina.html 
be gay: hence the saying 'God made me that way'; or else b) God is indifferent to someone being homosexual: 'God doesn't care'. If the former (assuming God would not inflict on someone a disordered condition apt to issue in sin) then it is not a malady and it is not wrong to engage in homosexual acts; if the latter then either the same implication holds or else God is irresponsible.

Whatever the intelligibility of the desire that homosexuality not be inborn, and thereby perhaps more likely to be remediable, it not a rational ground on which to assert that is an exclusively post-natal developmental psychological condition. As regards the theological reasoning, neither of the stated implications would follow from it being inborn. In general it is a mistake to infer from the principle of creation that God made everything to be as it is. God creates and sustains a world of natural agents, but those agents then interact with one another according to their abilities and liabilities in ways that have consequences which God allows but need not directly will. There are all sorts of disorders occurring in animals some caused by genetic factors, some by embryological ones, some by post-natal developmental conditions, some by trauma, and so on. From that fact that God made nature it does not follow that God made creatures this or that way, though it does follow that he permitted such things to occur. Anyone regarding that as an unacceptable position had better have some other account of how things are not perfect. Besides which, it does not follow from the fact that God permits a condition that he endorses or values it or wishes to see it lived out, or that he is indifferent to these issues.

It is largely an empirical question what the nature and causes of homosexuality may be and I do not think that we understand either. It seems likely on the basis of a broad range of empirical studies that embryological development and environmental factors combine to establish a certain sexual orientation. But whether or not this is the case what is more important is that between orientation and habitual action lies disposition. The Vatican use of 'deeply rooted homosexual tendencies' is relevant here in part because it suggests agnosticism regarding the cause of these but also because the notion of a tendency is closer to that of a disposition than to that of an orientation.

If one has a certain sexual orientation or direction this need not lead to active sexual practice and whether it does or not depends on the development or inhibition of dispositions. To be disposed is to be primed to act or react in certain ways. So, if one has an orientation but does not wish to find oneself acting or being strongly inclined to act in accord with it then one needs to attend to one's dispositions. This is where the Church's teaching or an interpretation of it, and its application in realtion to admission to and training for religious life have tended to be negligent. What should be said to those entering the celibate life is that while their orientations may not matter their tendenceies and dispositions certainly do. Whether heterosexually, homosexually or otherwise oriented they must develop strong counter-dispositions to act on these. In other and older words, they must cultivate sexual asceticism.

In the discussions about celibacy one issue that has been overlooked is that an argument from the legitimacy of sexual orientation being expressed in sexual activity, conjoined with the acceptance of the legitimacy of homosexual orientation, yields the conclusion that active homosexuality is thereby sanctioned. The only principled way to resist the conclusion is to argue that the proper meaning and role of sexual activity is in relation to the biological complementarity of male and female including but not exhausted 
by its generative function. This is not the occasion to pursue that issue, but bishops, religious superiors, and directors of seminaries need to attend to the four-fold distinction: orientation, tendency, disposition and activity (which in terms of the scholastic Aristotelian categories some might once have been taught correspond to different levels of potentiality and actuality: for Aristotle dunamis and energeia). And having learned that, the task is to apply it practically to establish a barrier so as to inhibit the occurrence of the fourth. That wall needs to be placed after orientation, for by the time tendencies and dispositions have developed it is likely to be too late to prevent their expression in activity; or certainly difficult to counter that tendency.

In many cases it is too late and only heroic corrective efforts assisted by grace will enable individuals to curtail their active proclivities. Their superiors, some of whom may themselves be in the same moral and spiritual danger, need to encourage asceticism, to insist upon it in the seminaries and religious houses of study and to require the departure of those unable or unwilling to take the necessary measures, either as staff or students.

One reason for reluctance, additional to possible compromise and fear of controversy, is the concern over the perilously low number of vocations. It is hard to predict outcomes but I suspect that a determined treatment of the issue of sexual disposition homosexual and heterosexual - with effective ascetical training would in fact make the priesthood and religious life more attractive to those of well-ordered sexual character. Additionally, as it became known that having had this problem the Church had dealt with it, the priesthood might recover something of the standing and regard it previously enjoyed at least among faithful Catholics. At any rate, no good outcome can be hoped for until this painful nettle is grasped, but the task will be made easier and the remedy more likely to be effective by the cultivation of spiritual virtues.

\section{Catholic Idolatry and Pelagianism}

Finally, I should like to comment briefly on the way in which Catholics beginning in the US but now throughout the West have absorbed and internalized as matters of faith, which they are not, the prevailing cultural and political norms of progressive and conservative sections of secular society. The first thing to note is the destructive effects of this, including a corruption of conscience, excusing among one's own what one would condemn in one's opponents, and a lack of charity regarding the motives and behaviour of anyone with whom one disagrees. There is also a form of displacement of the attention due to God towards moral causes: in the case of the right towards battling against abortion, euthanasia and homosexuality; in the case of the left towards campaigning against world poverty, capital punishment and global warming.

Both Jesus and Paul are strong in their denunciation of idolatry, i.e. the putting in place of God, and worship of God, various forms of natural or human construction, including 'works'. Paul is also very clear that nothing human beings do matters so far as their salvation is concerned save to the extent that it is redeemed by the grace of Christ's sacrifice and that sacrifice alone. This warns us against the spiritual vice of meritorianism: religious pride is pharisaism. This fact is relevant to the neo-Tridentine understanding of 'the Church' upon which many traditionalists are fixated which is a conception fashioned 
in the sixteenth century based on a recapitulation of what was then understood of the Apostolic, late Roman, medieval and scholastic periods, largely in uneasy isolation from the Church in the East, and in determined opposition to the arguments of various reformers. It is naïve to interpret the texts and modes of Trent apart from the conclusions of earlier theological debates and from their contemporary influences and cultural styles. Similarly liberals invest their hopes and sense of religious identity and purpose in another understanding of Church, that which they associate with Vatican II, thereby raising a historical event and artifact conditioned like Trent by its times, circumstances and oppositions into an object of effective devotion. Of course the Church as the mystical body of Christ is a divine institution, but that is not, as Trent and Vatican II each were, a human construction and it is important to avoid treating those as idols.

More generally, if liberals or traditionalist critics are right in their extensive criticisms of the current Church then why on earth should anyone else begin to take seriously its claims to divine foundation and inerrancy? More mundanely, at a time when the rest of society is either denouncing or more generally forgetting religion, it is sad, mad and bad for believers to set about one another, generally out of motives that are not themselves essentially religious. We need to do better as individuals and we need to do better as representatives of Christianity. So how to proceed? First, we need to draw several distinctions: political, cultural and theological. Whether one is conservative or liberal, traditional or progressive is extraneous to the theological contrast between the orthodox and the heterodox. What the Church proclaims and requires is orthodoxy and orthopraxy. Cultural and political positions, to the extent that they do not clash with this, are not matters for the Faith.

In his response to Cardinal O'Brien's address on behalf of the Scottish Catholic Bishops during their 2010 ad limina visit to Rome, Pope Benedict recalled the distinction between the lay ministry and the lay apostolate. The former notion has its origins in the US Catholic Bishops' acknowledgement of the growing contribution of pastoral co-workers, but as the Pope indicated it is liable to confuse roles and distract from the special calling of the laity. Addressing the latter, I would say that our priorities should be to equip ourselves with historical understanding, theological knowledge, analytical and critical methods and spiritual humility so as to engage with the principal challenges to Christian faith and Catholic doctrine.

Contrary to what is increasingly assumed by opponents and advocates, Catholicism is not first and foremost about sexual ethics, or abortion, or liturgy, or justice and peace, or environmental stewardship. Rather it is about coming to know, to love and to serve God. Perhaps the rest follows, but it follows and does not lead, and nor is it an acceptable substitute for faith. That was the mistake of Pelagius: to believe that we can be saved by moral endeavor.

The true Catholic teaching is that without grace we cannot be saved, and that grace is freely given and unmerited, though it can be co-operated with: not by doing what we determine to be good, but by doing what we discern to be the command of God. And to determine this we need to engage in discussion with others, sharing and probing convictions. Such engagement is likely at times to be vigorous and robust, but so long as it is in fidelity to the historic faith received and handed on by the apostles, and taught by the 
Creeds and Councils, and is conducted in charity, then it is as sure as anything in this world could be.

Much of what I have said conforms to Yogi Berra's comment about it being Déjà vu all over again, but if the symptoms persist or recur it is reasonable to repeat the diagnosis and proposed treatment and here another of his meaningful malapropisms is also relevant: 'When you come to a fork in the road, take it'. In the current crisis arising most recently from the Philadelphia grand jury report and Archbishop Vigano's accusations, each invoked and bolstered by critics of the leadership of the Church, some say we should be investigating clericalism and others that we should looking to extensive and in some cases mutual violation of clerical celibacy. We should realise that these are not exclusive options and we should be doing both, and other things besides, all with a view to re-establishing a sense of the sacred calling of the priesthood and religious life and the salvific function of the Church, not as a human institution but as a divine one.

We have too long been inclined to treat Christ's promise that the gates of hell will not prevail against his Church as an assurance that not only the visible but the local Church will survive; but there is no reason to believe that and some reason to disbelieve it, at least so far as concerns the Church in the countries where in former times it grew abundantly and flourished. Certainly, as Yogi said, 'it ain't over till it's over', and scandals like the poor will always be with us until the end of the world. As in the case of care for the needy, however, that is not reason either to ignore or to despair at them. In the case of the Church the best course would be to think less about it as a human institution and more about it it as a vehicle of sanctification. The scandal of the scandals is that it obscures that identity and undermines belief in the holiness of the Church. Time then for a mission of respiritualisation for which what is most important is not the number but the quality of the missionaries.

John Haldane Baylor University and

University of St Andrews 